\title{
SOME PHYSICAL PROPERTIES OF APRICOT PITS
}

\section{Tayle,S.A* ， EL Nakib,A.A* , Zaalouk,A.K** , Ahmed,A.N***}

\section{ABSTRACT}

The physical properties of apricot pits and apricot kernel are necessary for the design of equipments for processing, transportation, sorting, and breaking. In this study, some physical properties of pits and kernels were evaluated as function of moisture content varying from 8 to $19 \%$ for apricot pits and $24 \%$ for apricot kernels.

Apricot pits, in this moisture range, pit length, width, thickness and geometric diameter increased from ( 20.81 to $22.53 \mathrm{~mm}$ ), ( 17.44 to $18.02 \mathrm{~mm}$ ), (11.38 to $11.66 \mathrm{~mm})$ and ( 15.9 to $16.1 \mathrm{~mm}$ ), respectively, the projected area increased from 2.90 to $3.21 \mathrm{~cm}^{2}$, the porosity increased from 49 to $58 \%$, the volume increased from 0.16 to $0.17 \mathrm{~cm}^{3}$, the mass increased from 1.75 to $1.84 \mathrm{~g}$, bulk and true densities increased from 507 to $570 \mathrm{~kg} / \mathrm{m}^{3}$ and 1020 to $1160 \mathrm{~kg} / \mathrm{m}^{3}$ respectively, the rupture force of apricot pits decreased from ( 1397.9 to $581 . .4 \mathrm{~N}$ ), ( 1177.2 to $341.97 \mathrm{~N}$ ) and ( 632.94 tol86.39 $\mathrm{N}$ ) at $X, Y$ and $Z$ axes respectively, the angle of repose increased from 32.6 to $40.49^{\circ}$ and the coefficient of static friction increased from ( 0.41 to 0.77 ), (0.65 to 0.80 ),( 0.43 to 0.55 ), (0.40 to 0.51 ) and ( 0.22 to 0.26 ) for cardboard, rubber, wood, iron and glass respectively.

The apricot kernels, dimension properties (length, width and thickness) were $15.29,10.41$ and $5.27 \mathrm{~mm}$ respectively, the mass was $0.48 \mathrm{~g}$, the volume was $0.62 \mathrm{~cm}^{3}$, the bulk and true densities were 497 and 840 $\mathrm{kg} / \mathrm{m}^{3}$ respectively, the geometric diameter was $9.32 \mathrm{~mm}$, the sphercity was $59 \%$ and the porosity was $42 \%$.

\section{NTRODUCTION}

pricot (Prunus armeniaca L.) is classified under the prunus
species of Prunaidea sub-family of the Rosaceae family of the
Rosales group. Apricot has an important role in human nutrition and apricot fruits can be used as fresh, dried or processed fruit. It can be made into juice, marmalade, jam, and jelly. (Gezer et al., 2002)

\footnotetext{
* Prof. Emeritus of Ag. Eng. Dep., Fac. of Ag. Al-Azhar Uni. -Cairo, Egypt. ** Assistant Prof. of Ag. Eng. Dep., Fac. of Ag. Al- Azhar Uni. -Cairo, Egypt. ***An Agric. Eng.
} 
The apricot kernel contains $17.38 \%$ protein, $48.70 \%$ crude oil, $3.68 \%$ Na, 1.06 ppm P, 0.58 ppm K, 0.11 ppm Ca, 0.24 ppm Mg, 42.8 pm Fe, 42.35 ppm Zn, 1.10 ppm Mn, 2.09 ppm.Cu (Özcan 2000).

Apricot kernel contains $40 \%$ oil which is composed of $30 \%$ linoleic acid (C18:2) and 60\% oleic acid (C18:1). Linoleic acid is an essential fatty acid. Essential fatty acids and their longer chain-molecular products are necessary for maintenance of growth and reproduction (Eastwood, 1997).

The stone of apricot are used in the production of oils, Benz al de Hyde, cosmetics, active carbon, aroma perfume, and food after remove glycoside amygdaline, (Vursavus and Faruk 2004)

In Egypt the annual production apricot about 78500 tons apricot stone from this production, Most of the apricots are produced in Al-Qulybia and Al-Fayome. (FAO2007).

Important applications of activated carbons are related to their use in water and industrial wastewater treatment for removal of flavor, color, odor and other undesirable organic impurities. Activated carbon has found increasing application in the field of hydrometallurgy, especially in the recovery of gold and silver from cyanide solutions (Dorbrowksi 2001)

Mohsenin ( 1970 ) reported that the physical properties of materials such as, shape, size, volume and surface area are important in many problems associated with design or development of a specific machine, analysis of the behavior of the product in handling of material, stress distribution in the material under load .

Kaleem et al. ( 1993) reported that the angle of repose is very important in determining the inclination angle of the machine hopper tank.

Deshpande et al. (1993) found that the surface area of soya bean grain increased from 81.3 to $95.2 \mathrm{~mm}^{2}$, when the moisture content was increased from 8.7 to $25 \%$ w.b. 
GÜner et al. (2004) reported that rupture strength values of apricot pit and apricot kernel, respectively. Rupture strength values of apricot pit and apricot kernel decreased as the moisture content increased.

Gezer et .al (2002) reported that, various some physical properties of pits and kernels of Hacihaliloglu apricots were evaluated as a function of moisture content varying from $6.79 \%$ to $36.19 \%$ d.b. for apricot pits and from $6.95 \%$ to $38.76 \%$ d.b. for apricot kernels .

In apricot pits, dimensional properties and weight increased; the sphericity decreased from 0.6537 to 0.6526 ; the thousand grain mass increased from 1720 to $2028 \mathrm{~g}$; bulk density increased form 463 to 581 $\mathrm{kg} / \mathrm{m}^{3}$, grain volume increased from 1626 to $1746 \mathrm{~mm}^{3}$, volume weight increased from 1053 to $1161 \mathrm{~kg} / \mathrm{m}^{3}$, terminal velocity increased from 7.11 to $7.76 \mathrm{~m} / \mathrm{s}$; the projected area increased

From 2.985 to $3.539 \mathrm{~cm}^{2}$, the porosity increased from $43.96 \%$ to $50.03 \%$; the rupture strength of apricot pits decreased from 514.03 to $315.89 \mathrm{~N}$; and the coefficient of static friction of apricot pits increased as the moisture content increased.

In apricot kernels, however, dimensional properties and weight increased; the sphericity increased from 0.5879 to 0.7164 ; the thousand grain mass increased from 473 to $616 \mathrm{~g}$; bulk density decreased from 559 to $545 \mathrm{~kg} / \mathrm{m}^{3}$, grain volume increased from 497 to $573 \mathrm{~mm}^{3}$, true density increased from 1003 to $1094 \mathrm{~kg} / \mathrm{m}^{3}$, terminal velocity increased from 5.37 to $6.68 \mathrm{~m} / \mathrm{s}$; the projected area increased

From 1.293 to $1.519 \mathrm{~cm}^{2}$, the porosity decreased from $55.70 \%$ to 49.70 $\%$; rupture strength of apricot kernels decreased from 63.28 to $44.13 \mathrm{~N}$; and the coefficient of static friction increased as the moisture content increased.

$\operatorname{Baryeh}(2000)$ found that the volume variation with moisture content., The volume increases with moisture content from $425 \mathrm{~mm}^{3}$ at $5 \%$ moisture content to $900 \mathrm{~mm}^{3}$ at $25 \%$ moisture content. After $25 \%$ moisture content, the volume changes very little. He added that the variation of the angle of repose with moisture content, The angle of repose increases non-linearly with grain moisture content from $19.8^{\circ}$ at 
$5 \%$ moisture content to $23.5^{\circ}$ at $20 \%$ moisture content and decreases gently thereafter to $21^{\circ}$ at $35 \%$ moisture content

Vursvus and Faruk ( 2004 ) reported that, various physical properties of apricot pits were evaluated as a function of moisture content varying from $6.38 \%$ to $39.33 \%$ d.b. for apricot pits and from $6.59 \%$ to $41.46 \%$ d.b. for apricot kernels.

In apricot pits, the average length increased from 28.89 to $31.20 \mathrm{~mm}$, the average the width increased from 15.92 to $17.43 \mathrm{~mm}$ and the average the thickness increased from 9.96 to $10.75 \mathrm{~mm}$. They added that by increasing moisture content the thousand grains mass increased from 1950 to $2590 \mathrm{~g}$.

In apricot kernels, the average length increased from 19.17 to $20.69 \mathrm{~mm}$, the average width increased from 9.99 to $10.43 \mathrm{~mm}$ and the average the thickness increased from 5.74 to $7.08 \mathrm{~mm}$. they added that by increasing moisture content the thousand grains mass increased from 480 to $650 \mathrm{~g}$.

Aydin (2002) reported that the porosity of hazel nut depend on the bulk as well as true densities; the magnitude of variation in porosity depends on these factors only. The porosity of nut was found to slightly increase with increase in moisture content from 2.87 to $19.98 \%$ w.b. The porosity of kernel was found to slightly increase with increase in moisture content from 2.77 to $19.89 \%$ w.b. He added that, the projected area of hazel nut increased by about $17.99 \%$, with increase in moisture content of nut .Furthermore, the projected area of kernel increased by about $16.4 \%$, with increase in moisture content

Aydin (2003) reported that the true density of almond nut at different moisture levels varied from 1015 to $1115 \mathrm{~kg} / \mathrm{m}^{3}$ at the moisture range from 2.77 to $24.97 \% \mathrm{wb}$. The effect of moisture content on true density of almond nut showed an increase with moisture content. Effect of moisture content on true density of kernel showed an increase with moisture content from 900 to $995 \mathrm{~kg} / \mathrm{m}^{3}$ at the moisture range from 2.77 to $24.97 \%$ wb.

Ozdemir and Akinci (2004) reported that the static coefficient of friction for hazelnuts and kernels was determined on the plywood 
surface. These coefficient values varied from 0.212 to 0.296 and 0.298 to 0.376 , respectively. On the galvanized iron sheet, the static coefficient of friction for hazelnuts and kernels were found to be statistically insignificant, varying from 0.221 to 0.242 and from 0.271 to 0.297 , respectively

Yildiz (2005) reported that the variation of the coefficient of static friction with moisture content in mash bean seeds, for iron sheet and galvanized iron sheets. That the coefficient of static friction values on an iron sheet and one galvanized iron sheet increased with the increase of moisture content. The coefficient of static friction increased from 0.270 to 0.322 and from 0.302 to 0.367 for galvanized iron sheet and iron sheet respectively. He added that the projected areas values of mash bean seeds at moisture contents of 6.66 and $18.59 \%$ varied from 0.140 to $0.213 \mathrm{~cm}^{2}$.

\section{MATERIALS AND METHODS}

To achieve the large of this experimental work, selected variety main namely

( Almara ). The apricot pits samples were cleaned to removed all foreign materials and divided into three samples randomly order to obtain three different levels of moisture content. The apricot pits desired moisture content levels were achieved by incubated in water for 1 and 2 hours before the experiment (Inan 2001).

\section{A- Materials :}

The study was carried out using local variety namely (Alamar)

\section{B- Measuring instrumentation :}

1- Digital vernire caliper :

It was used for measuring the dimensions of apricot pits and apricot kernel.

2- Electrical balance: accuracy $0.01 \mathrm{~g}$.

3- Electrical oven with forced hot air circulation.

\section{C- Experimental procedures :}


The main experiments were conducted to determine and calculated the physical and mechanical properties of apricot variety under study. Apricot pit and apricot kernel dimensions ( length, width and thickness ), mass, volume, geometric diameter, bulk and real densities, percent of sphericity, projected area, angle of repose and coefficient of friction were measured and estimated. All the experiments were replicated three times.

\section{1- Physical properties of apricot pits and apricot kernels :}

Pits and kernel dimensions ( $\mathrm{L}, \mathrm{W}$ and $\mathrm{T}$ ), mass, volume, geometric diameter, bulk and real densities, percent of sphericity and projected area . Standard deviation, coefficient of variation, maximum, minimum, and arithmetic mean .The calculated equations according to EL Raie et al. ( 1996 ) studies that, the size of apricot pits and kernels in terms of length ( $\mathrm{L}$ ), width ( $\mathrm{W}$ ) and thickness ( $\mathrm{T}$ ). The size was used to calculate geometric diameter $\left(D_{g}\right)$, percent of sphericity $(S)$ of the individual pits and kernels. The following equations were used to calculate the values of the above mentioned properties:

$$
\begin{aligned}
& \mathrm{V}=\pi / 6(\mathrm{LWT}) \\
& \mathrm{D}_{\mathrm{g}}=(\mathrm{LWT})^{1 / 3} \\
& \mathrm{~S}=(\mathrm{LWT})^{1 / 3} / \mathrm{L}
\end{aligned}
$$

\section{- Volume of individual pit and kernel :}

The pit and kernel volume were determined using the liquid displacement method. Toluene $\left(\mathrm{C}_{7} \mathrm{H}_{8}\right)$ was used in place of water because it is absorbed by pit to a lesser extent . Also, its surface tension is low, so that it fills even shallow drips in a pit and its dissolution power is low ( Mohsenin 1980 ) .

\section{- Real density of pit and kernel :}

Real density or individual pit and kernel density $\left(\rho_{\mathrm{r}}\right)$ : random samples of pits and kernels were used to calculate the pit and kernel density as follows :

$$
\rho_{r}=\frac{W}{V}
$$


PROCESS ENGINEERING

Where :

$\rho \mathrm{r}=$ the real density of the individual grain, $\mathrm{g} / \mathrm{cm} 3$;

$\mathrm{W}=$ Weight of the individual grain, $\mathrm{g}$;

$\mathrm{V}=$ Volume of the individual grain, $\mathrm{cm}^{3}$.

- Bulk density of pit and kernel :

It was calculated for pits and kernels by dividing the mass of a quantity of pits and kernels on its volume, which was measured by using a constant volume cylinder :

$$
\rho_{\mathrm{b}}=\mathrm{W}_{\mathrm{b}} / \mathrm{V}_{\mathrm{b}}
$$

Where :

$$
\begin{aligned}
& \rho_{\mathrm{b}}=\text { the bulk density of pits and kernels, } \mathrm{g} / \mathrm{cm}^{3} \\
& \mathrm{~W}_{\mathrm{b}}=\text { mass of the same quantity of pits and kernel, } \mathrm{g} \\
& \mathrm{V}_{\mathrm{b}}=\text { volume of the same quantity of pits and kernel, } \mathrm{cm}^{3}
\end{aligned}
$$

- The moisture content for apricot ( pits and kernels ) is evaluated according to the ASAE standards ( 1994 ) i.e., oven dried at $103^{\circ} \mathrm{C}$ for 24 hours .

\section{2- Mechanical properties of pits and kernel:}

- Repose angle $\theta^{\circ}$ : it is the angle between the horizontal base and inclined side of the formed cone due to free fall of pit or kernel sample . The horizontal base of the cone ( D ) and its height ( $h$ ) were measured by a ruler and repose angle cab be calculated as follows :

$$
\text { ton } \theta^{\circ}=\mathrm{h} / 0.5 \mathrm{D}
$$

- Friction angle $\phi^{\circ}$ : it was measured between different surfaces and apricot pits and kernels according to Mohsenin (1970).

-The hardness device:

The rupture strength values of stone were measured by forces applied through three axes (length, width and thickness). To determine the rupture strength of grains, hardness material test device has three main components $(\mathrm{X}, \mathrm{Y}$, and $\mathrm{Z}$ ) which are stable upend motion bottom of platform. 


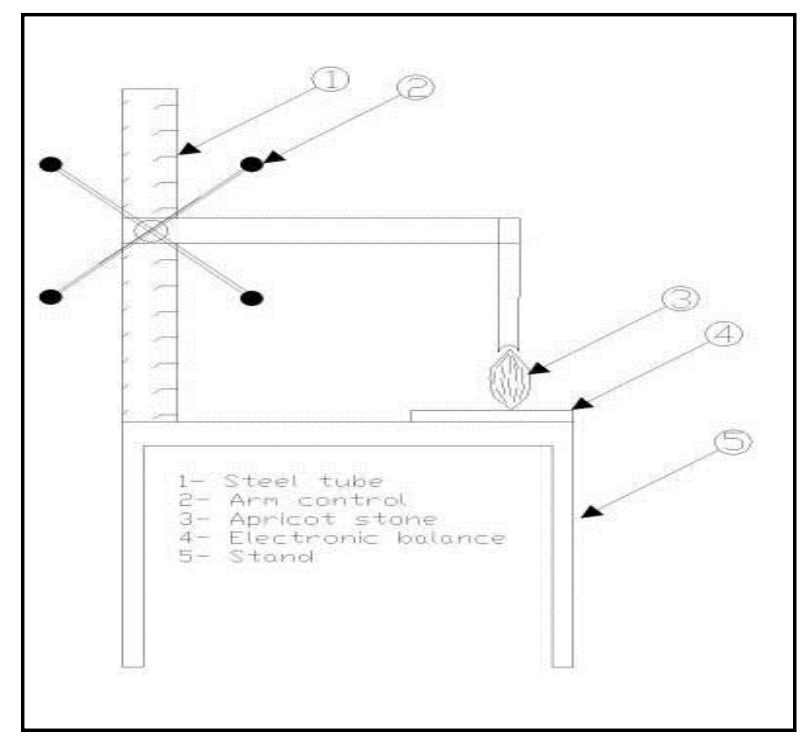

Fig. (1) Diagram of breakage taster

\section{RESULTS AND DISCUSSIONS}

\section{Linear dimension:}

The variations of length, width, thickness and geometric diameter the apricot pits and apricot pit moisture content are shown in fig. (2).

Dimensions along the three principle axis were from $8 \%$ up to $15 \%$ moisture content, there is no appreciable dimensional change, thereafter all dimensions increase with apricot pit moisture content from $15 \%$ up to $19 \%$. The pits probably retain some air voids as they absorb water which replaced with water from $8 \%$ up to $15 \%$ moisture content there by making the pits display no dimensional change.

The total average was largest along the pit length and least along its width and thickness.

While, the geometric diameter slightly increased with apricot pit moisture content increased. 
The dimensions of apricot kernel the length was ranged from 13.5 to $17.5 \mathrm{~mm}$ with mean value of $15.29 \mathrm{~mm}$, the width was ranged from 8.25 to $12.75 \mathrm{~mm}$ with a mean value of $10.47 \mathrm{~mm}$, the thickness was ranged from 4.5 to $6.3 \mathrm{~mm}$ with a mean value of $5.27 \mathrm{~mm}$ and the geometric diameter was ranged from 7.80 to $10.60 \mathrm{~mm}$ with a mean value of $9.32 \mathrm{~mm}$ at moisture content $24 \%$

\section{Bulk density, True density and Porosity :}

Bulk density, true density and porosity were measured for apricot pits . The results as shown in fig. (3) and (4) were found to be dependent on moisture content. The following linear regression equations described the relationship between each of bulk density $\left(\rho_{\mathrm{bp}}\right)$, true density $\left(\rho_{\mathrm{bt}}\right)$ and porosity $\left(\varepsilon_{\mathrm{p}}\right)$ and moisture content in percent ( d.b ).

$$
\begin{aligned}
& \rho_{\mathrm{bp}}=598.67-31.5 \mathrm{Mc} \quad \ldots \ldots \ldots \ldots \ldots \mathrm{R}^{2}=0.9763 \\
& \rho_{\mathrm{bt}}=1233.3-70 \mathrm{Mc} \quad \ldots \ldots \ldots \ldots \ldots \mathrm{R}^{2}=0.9932 \\
& \varepsilon_{\mathrm{p}}=61.667-4.5 \mathrm{Mc} \quad \ldots \ldots \ldots \ldots \ldots \mathrm{R}^{2}=0.9067
\end{aligned}
$$

These equations showed that each of bulk density, true density and porosity show in Fig. (5) for apricot pits. The bulk and true densities and porosity were evaluated as function of moisture content in the ranged from 8 to $19 \%$. The bulk and true densities and porosity increased form ( 507 to $570 \mathrm{~kg} / \mathrm{m}^{3}$ ), ( 1020 to $1160 \mathrm{~kg} / \mathrm{m}^{3}$ ) and ( 49 to $58 \%$ ) respectively .

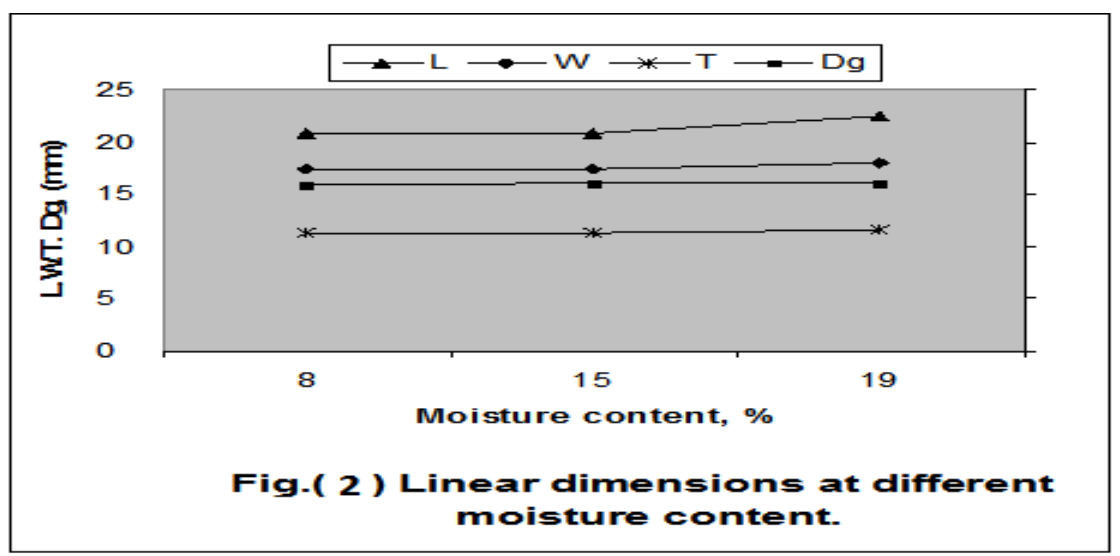



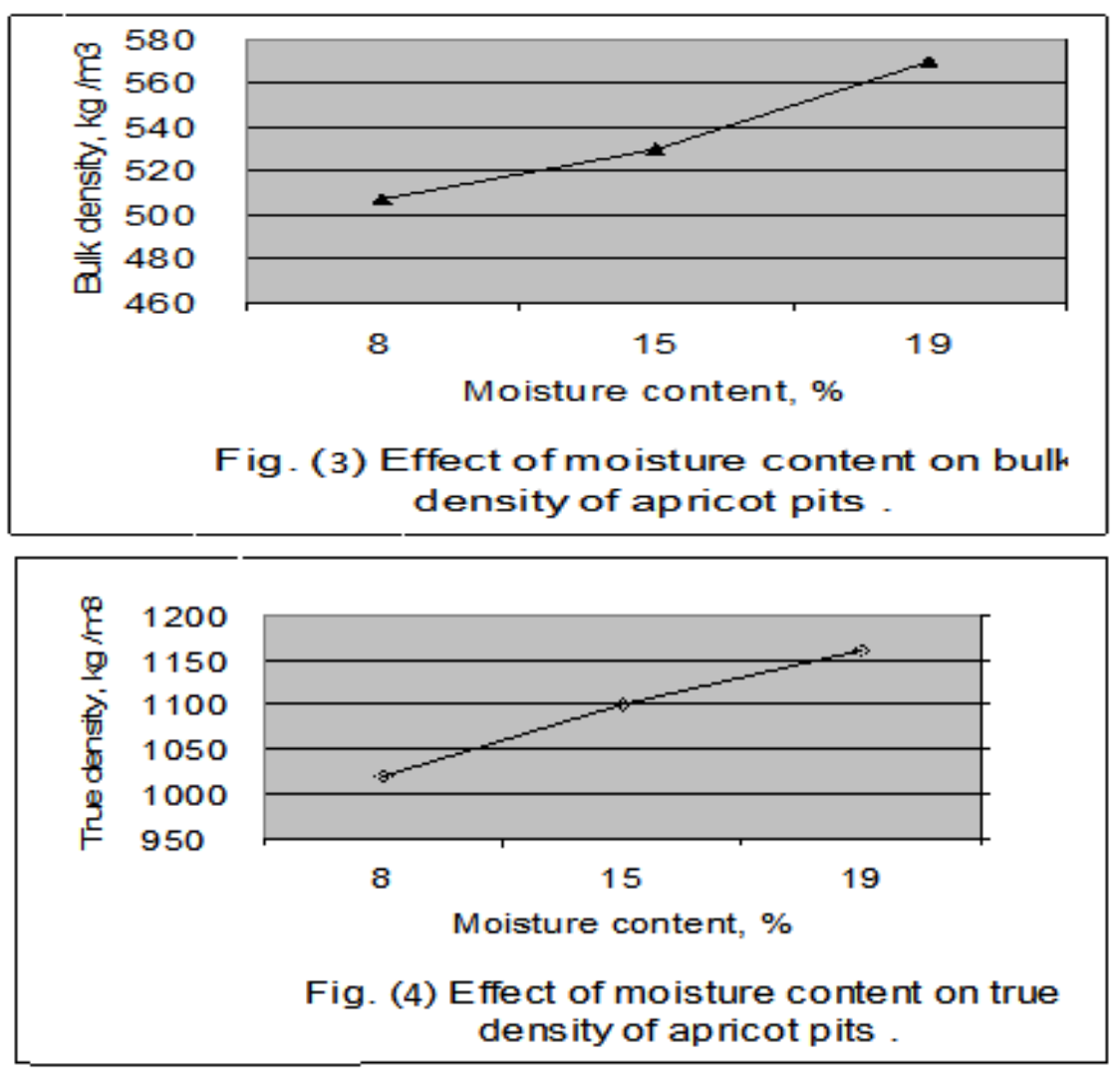

While, bulk and true densities and porosity were measured for apricot kernel at moisture content of $24 \%$.The bulk density were ranged from 445 to $535 \mathrm{~kg} / \mathrm{m}^{3}$ with mean value $497 \mathrm{~kg} / \mathrm{m}^{3}$, the true density were ranged from 795 to $895 \mathrm{~kg} / \mathrm{m}^{3}$ with mean value $840 \mathrm{~kg} / \mathrm{m}^{3}$ and the porosity ranged from 39.5 to $44.5 \%$ with mean value $42 \%$.

\section{Mass :}

The dependence of grain mass of apricot pits on moisture content were found to be between 1.75 to $1.84 \mathrm{~g}$. The apricot kernel mass were ranged from 0.40 to $0.63 \mathrm{~g}$ with a mean value $0.48 \mathrm{~g}$.

\section{Volume :}

The dependence of grain volume of apricot pits on moisture content were found to be between 0.16 to $0.17 \mathrm{~cm}^{3}$. The apricot kernel volume were ranged from 0.50 to $0.72 \mathrm{~cm}^{3}$ with a mean value $0.62 \mathrm{~cm}^{3}$ 
PROCESS ENGINEERING

\section{Rupture force :}

The force required to initiate pit rupture at different moisture content and compression axes is shown in fig.(6).

It can be observed that the force required to initiate pit rupture decreased along the $\mathrm{X}, \mathrm{Y}, \mathrm{Z}$ - axes as moisture content increased from 8 to 19 $\%$ wb.

Apricot pit compressed along the $\mathrm{X}$-axis required 1397.9, 773.0 and $581.4 \mathrm{~N}$ at moisture content of 8,15 and $19 \%$ respectively .

The relationship between moisture content and rupture force of apricot pit compressed along the $\mathrm{X}, \mathrm{Y}$ and $\mathrm{Z}$-axes can expressed equation as follows :

$$
\mathrm{F}_{\mathrm{X}}=100.93+403.25 \mathrm{Mc} \ldots \ldots \ldots \ldots \ldots \ldots \mathrm{R}^{2}=0.9142
$$

For compression along the $\mathrm{Y}$ - axis the rupture force decreased from 1177.2 to $341.97 \mathrm{~N}$ with increase in moisture content from 8 to $19 \%$.

The reason for this trend along the $\mathrm{X}$ and $\mathrm{Y}$ axes can be attributed to the fact

that at higher moisture content, shell became soft and weak and this was responsible for the reduction in rupture force .

The relationship between moisture content and rupture force of apricot pit compressed along the $\mathrm{Y}$-axis can expressed equation as follows :

$$
\mathrm{F}_{\mathrm{y}}=417.65 \mathrm{Mc}-172.37 \ldots \ldots \ldots \ldots \ldots \mathrm{R}^{2}=0.8617
$$

The relationship between moisture content and rupture force of apricot pit compressed along the $\mathrm{Z}$-axis can expressed equation as follows :

$$
\mathrm{F}_{\mathrm{z}}=223.25 \mathrm{Mc}-70.3 \ldots \ldots \ldots \ldots \ldots \ldots \ldots \mathrm{R}^{2}=0.9369
$$

\section{Angle of repose :}

Dynamic angle of repose for apricot pits as shown in fig ( 7 ) showed linear relationship the apricot pit moisture content . The following linear regression equation described the relationship between the dynamic repose angle $(\theta)$ in degree and moisture content percent . 
$\Theta=43.973-3.945 \mathrm{Mc}$

$$
\mathrm{R}^{2}=0.9605
$$

The angle of repose was evaluated as function of moisture content range of 8 to $19 \%$. The average the angle of repose increased from 32.60 to $40.49^{\circ}$.

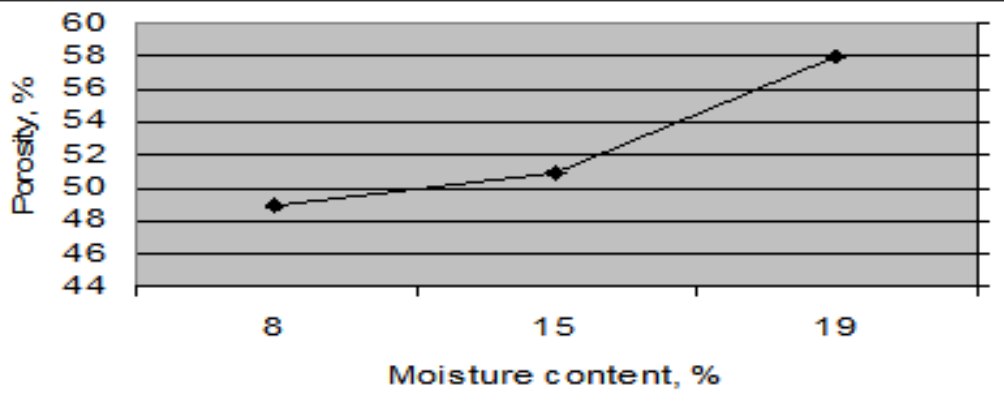

Fig. (5) Effect of moisture content on porosity of apricot pits.
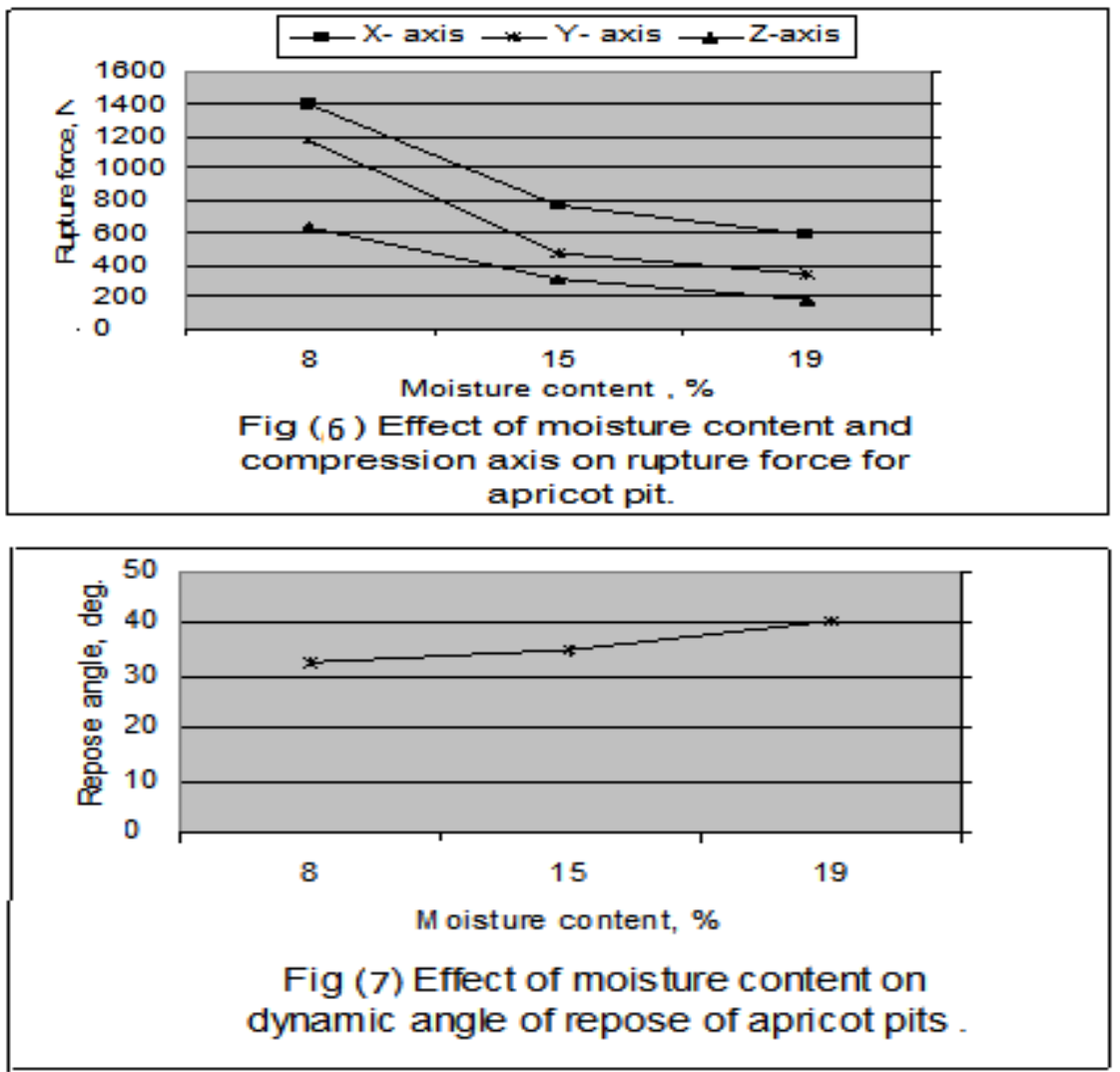

Misr J. Ag. Eng., January 2011 


\section{Static friction coefficient :}

The static coefficient of friction for apricot pits of the investigated on the selected materials surface including Carwboard, Rubber, Plywood, Iron sheet and Glass as shown in fig ( 8 ) appeared to be linearly dependent on the moisture content.

The relation ship between moisture content and static coefficient of friction carwboard $\left(\mu_{\mathrm{c}}\right)$, rubber $\left(\mu_{\mathrm{r}}\right)$, plywood $\left(\mu_{\mathrm{p}}\right)$, iron sheet $\left(\mu_{\mathrm{I}}\right)$ and glass $\left(\mu_{\mathrm{g}}\right)$ can be represented by the following linear regression equations :

$$
\begin{aligned}
\mu_{c} & =0.79-0.10 \mathrm{Mc} \ldots \ldots \ldots \ldots \ldots \ldots \ldots \mathrm{R}^{2}=0.9643 \\
\mu_{\mathrm{r}} & =0.8933-0.075 \mathrm{Mc} \ldots \ldots \ldots \ldots \ldots . . \mathrm{R}^{2}=0.848 \\
\mu_{\mathrm{p}} & =0.6133-0.06 \mathrm{Mc} \ldots \ldots \ldots \ldots \ldots \ldots \mathrm{R}^{2}=0.9908 \\
\mu_{\mathrm{I}} & =0.5767-0.055 \mathrm{Mc} \ldots \ldots \ldots \ldots \ldots . \mathrm{R}^{2}=0.8811 \\
\mu_{\mathrm{g}} & =0.2833-0.02 \mathrm{Mc} \ldots \ldots \ldots \ldots \ldots \ldots \mathrm{R}^{2}=0.9231
\end{aligned}
$$

The equations showed that the static coefficient of friction for apricot pits of the studied variety increased with increasing the moisture content at the studied range on each of the five material surfaces. At all moisture content levels for apricot pits, the highest values of static coefficient of friction were on rubber followed by cardboard, iron sheet and lowest on glass .

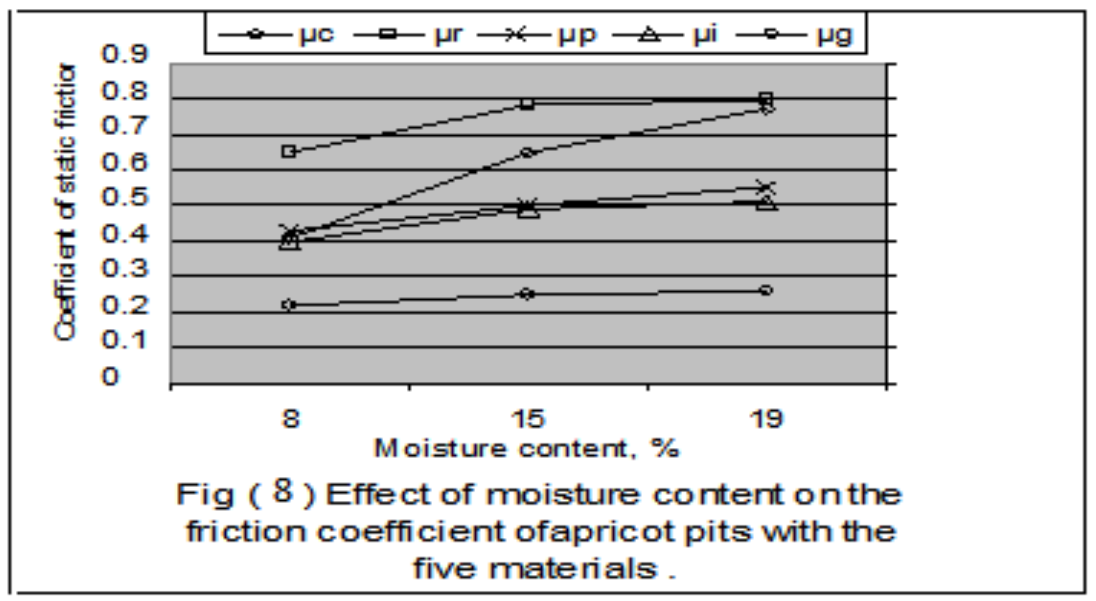




\section{CONCLUSION}

- The dimensional properties and mass of apricot pit increased depending on moisture content as following length, width, thickness and geometric diameter increased from ( 20.81 to $22.53 \mathrm{~mm}$ ), ( 17.44 to $18.02 \mathrm{~mm}),(11.38$ to $11.66 \mathrm{~mm}$ ) and ( 15.9 to $16.1 \mathrm{~mm}$ ), respectively .

The mass, bulk, true densities and volume increased with moisture content as following, from 1.75 to $1.84 \mathrm{~g}$, from 507 to 570 $\mathrm{kg} / \mathrm{m}^{3}, 1020$ to $1160 \mathrm{~kg} / \mathrm{m}^{3}$ and from 0.16 to $0.17 \mathrm{~cm}^{3}$ respectively.

- $\quad$ The rupture force on both axes decreased with moisture content in apricot pit as following:

- $\quad$ The relationships between moisture content and rupture force of apricot pit compressed along the $\mathrm{X}, \mathrm{Y}$ and $\mathrm{Z}$-axes can expressed equations as follows :

$$
\begin{aligned}
& F_{x}=100.93+403.25 \mathrm{Mc} \ldots \ldots \ldots \ldots \ldots \ldots \ldots \mathrm{R}^{2}=0.9142 \\
& \mathrm{~F}_{\mathrm{y}}=417.65 \mathrm{Mc}-172.37 \ldots \ldots \ldots \ldots \ldots \ldots \mathrm{R}^{2}=0.8617 \\
& \mathrm{~F}_{\mathrm{z}}=223.25 \mathrm{Mc}-70.3 \ldots \ldots \ldots \ldots \ldots \ldots \ldots \mathrm{R}^{2}=0.9369
\end{aligned}
$$

The porosity and angle of repose increased with moisture content in apricot pit as following from 49 to $58 \%$, and. from 32.6 to $40.49^{\circ}$ respectively.

-The coefficient of static friction increased from ( 0.41 to 0.77$)$, (0.65 to $0.80),(0.43$ to 0.55$),(0.40$ to 0.51$)$ and $(0.22$ to 0.26$)$ for cardboard, rubber, wood, iron and glass respectively.

The apricot kernels, dimension properties (length, width and thickness) were $15.29,10.41$ and $5.27 \mathrm{~mm}$ respectively, the mass was $0.48 \mathrm{~g}$, the volume was $0.62 \mathrm{~cm}^{3}$, the bulk and true densities were 497 and 840 $\mathrm{kg} / \mathrm{m}^{3}$ respectively, the geometric diameter was $9.32 \mathrm{~mm}$, the sphercity was $59 \%$ and the porosity was $42 \%$.

\section{REFERENCES}

Aydin, C. (2002). Physical properties of hazelnuts. Biosystems Engineering, 82, 297-303.

Aydın, C. (2003). Physical properties of almond nut and kernel. Journal of Food Engineering, 60, 315-320. 
Baryeh, E. A. (2000). Physical properties of millet. Journal of Agricultural Engineering Research, submitted.

Desphande, S. D., Bal, S., and Ojha, T. P. (1993). Physical properties of soybean. Journal of Agricultural Engineering Research, 56, 8998 .

Dorbrowksi, (2001) Adv. Colloid Interface Sci. 93:135.

Eastwood, M. (1997). Principles of Human Nutrition London Chapman and Hall. 121- 135.

EL - Raie, A.E.S., N.A. Hendawy and A.Z.Taib( 1996) A study of physical and engineering properties for some agricultural products. Misr J. Ag. Eng. 13 (1) : 211-236.

FAO 2007

Gezer, I., Haciseferogullari, H., and Demir, F. (2002). Some physical properties of Hachalilo glu apricot pit and its kernel. Journal of Food Engineering, 56, 49-57 .

Güner. M. and R. Keskin. (2004) Mechanical removal of sulphuretted apricot pit. Biosystems Engineering 88(2) :187-192.

Kaleem, F.H., Z.E.Ismail and G.R. Abd-Hakim( 1993) Factors affecting grain cleaning efficiency . Part1: Grian straw mixture and characteristics, Misr J.Ag.Eng.10(2): 369-382.

İnan.A,( 2001) On the feasibility of a novel apricot stone cracking machine, F.Ü. Fen ve Müh. Bilimleri Dergisi 13, 2, 211-223.

Mohsenin, N. N. (1970). Physical properties of plant and animal materials. New York: Gordon and Breach Science Publishers.

Mohsenin, N. N. (1982). Physical properties of plant and animal materials.New York: Gordon and Breach Science Publishers.

Özcan,M • (2000). Composition of some apricot (Prunus armeniaca L.) kernels grown in Turkey. Acta Alimentaria, 29(3), 289-293. 
Ozdemir .F and Akinci . I. (2004), Physical and nutritional properties of four major commercial Turkish hazelnut varieties Journal of food Engineering , 63, 341- 347 .

Vursavus k. and Faruk.(2004). Mechanical behaviour of apricot pit under compression loading. Journal of Food Engineering $65255-$ 261.

Yildiz .M. Ŭgur (2005), Some physical properties of mash bean (Phaseolus aureus L.)seeds cultived in turkey, S.Ü. Ziraat Fakültesi Dergisi 19 (35) 41-45.

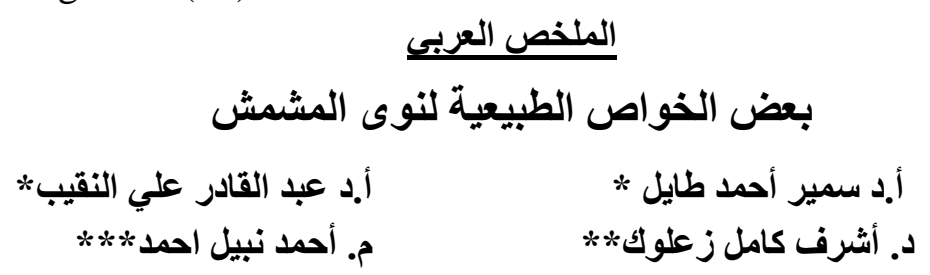

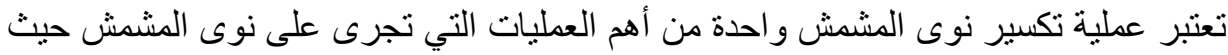

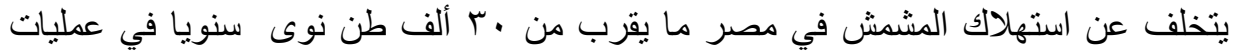

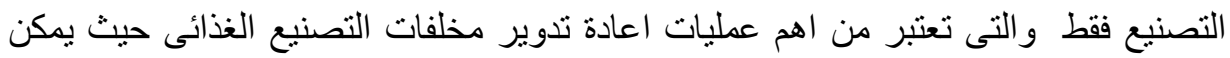

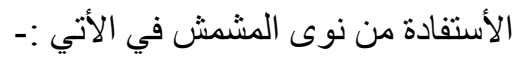

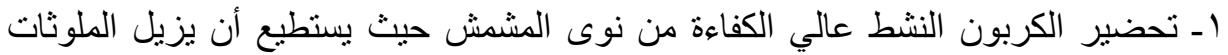

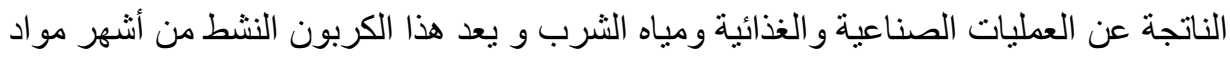

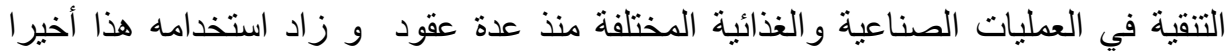

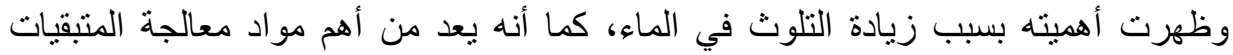

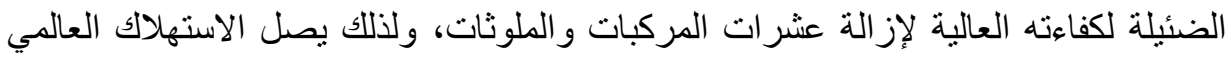

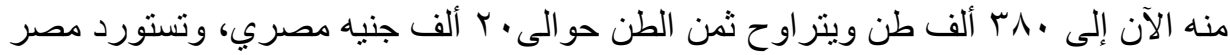

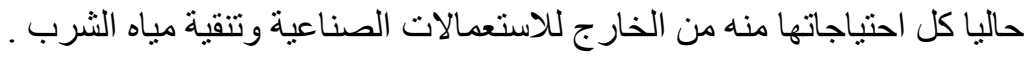

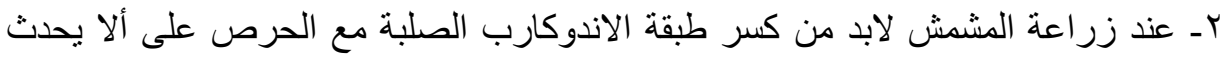

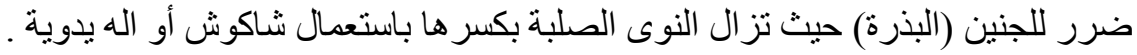

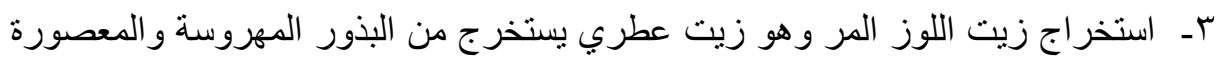

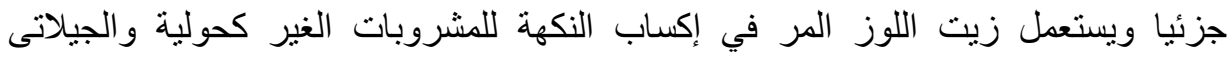

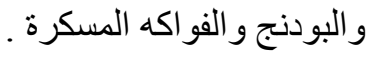


ع ـ تؤكل بعد إزالة الطعم المر الناتج عن جليكوزيد الامجدالين أو بإضافة كمية قليلة للتو ابل

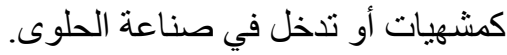

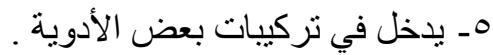

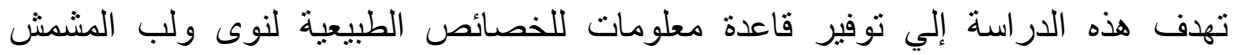

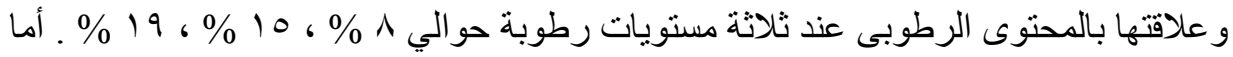

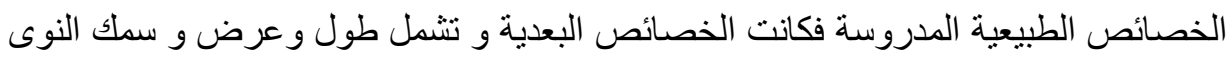

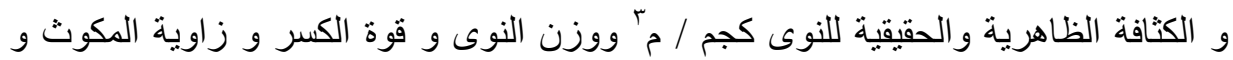

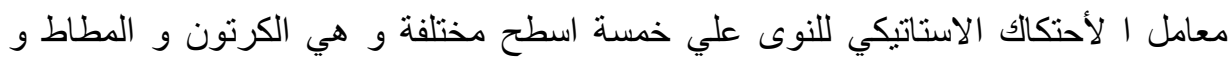

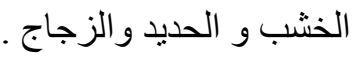

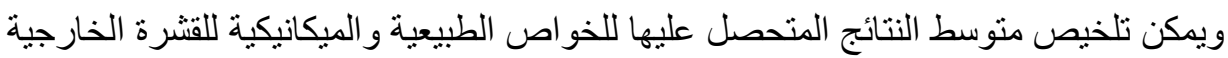

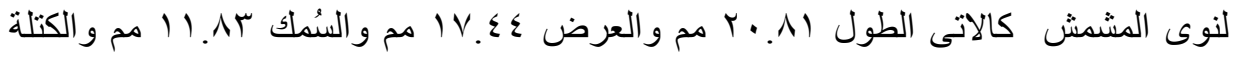

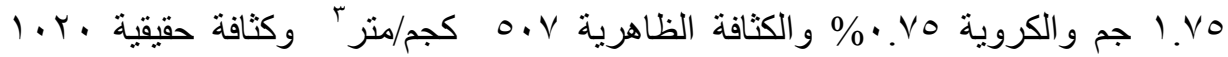

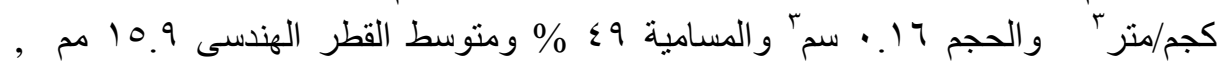

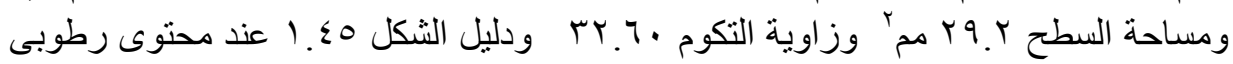
1 \% على الترتيب. تم دراسة قوة الكسر الو اقعة على القشرة الخارجية لنوى المشمش على التى الثلاث اتجاهات التهات و النتائج

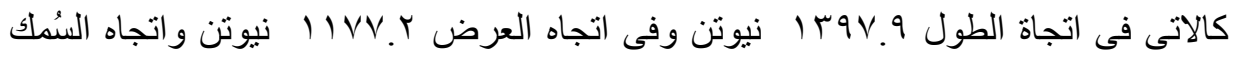

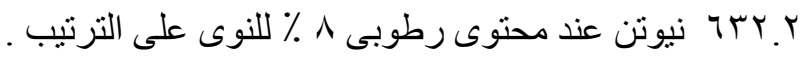
و العلاقة بين رطوبة النوى وقوة الكسر على رطوب الثنلاث محاور لنوى لنوى المشمش كما هو مبين

$\mathrm{F}_{\mathrm{X}}=100.93+403.25 \mathrm{Mc}$

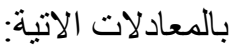

$\mathrm{F}_{\mathrm{y}}=417.65 \mathrm{Mc}-172.37$ $\mathrm{R}^{2}=0.9142$

$\mathrm{F}_{\mathrm{z}}=223.25 \mathrm{Mc}-70.3$ $\mathrm{R}^{2}=0.8617$ $R^{2}=0.9369$

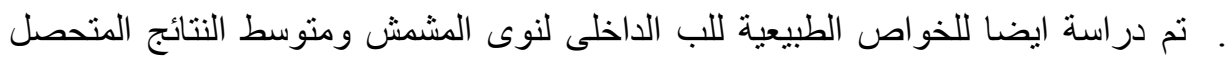

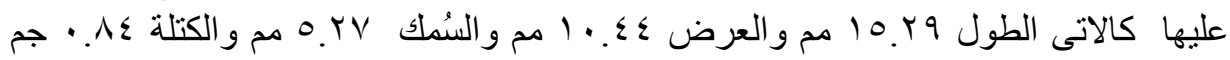

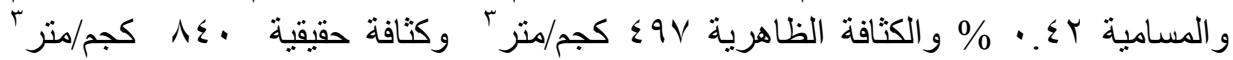

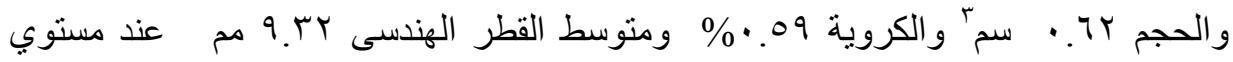

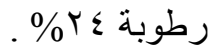

